\title{
Energy metabolism reactions in ruminant muscle: responses to age, nutrition and hormonal status*
}

\author{
GE Lobley
}

Rowett Research Institute, Bucksburn, Aberdeen AB2 9SB, Scotland, UK

(Received 22 May 1989; accepted 17 October 1989)

\begin{abstract}
Summary - Energy expenditure in muscle comprises reactions related to intermediary metabolism and those of posture and activity. The metabolic reactions respond to a wide range of nutritional and hormonal stimuli and are often apparently co-ordinated; in magnitude, however, their contribution to energy requirements can be minor compared with locomotion and posture. Metabolic reactions include protein turnover, ion transport and substrate cycles. In young ruminants muscle protein synthesis responds to intake but effects on energy expenditure are less pronounced; the situation with the adult is unclear. The involvement of insulin in ruminants may differ from that in monogastrics but effects are observed with thyroid hormones. Ruminant muscle may have a higher energy requirement for $\mathrm{Na}^{+}, \mathrm{K}+$ transport which responds in proportion to total oxygen uptake to alterations in intake. Thyroid hormone treatment and, probably, the catecholamines enhance both $\mathrm{Na}^{+}, \mathrm{K}+$ and $\mathrm{Ca}^{2+}$ transport. Muscle has fewer substrate cycles than liver and each may contribute only $1-3 \%$ toward oxygen consumption. Several are sensitive to insulin, but larger responses are observed with thyroxine and epinephrine and under stress conditions, therefore, may account for significant proportions of heat increment. Energy costs of standing may be considerable and posture movements may change with diet quality and quantity. Locomotory activity may mask changes in the contribution of metabolic reactions in response to different stimuli.

Approximately $80 \%$ of energy costs for muscle in vivo are accounted for by protein turnover (20$25 \%)$, ion transport $(25-30 \%)$, substrate cycling $(5-8 \%)$ and standing $(30 \%)$. Better integration of experiments in vivo and in vitro is required to improve the quantification and resolve data anomalies.
\end{abstract}

skeletal muscle / ruminant / energy expenditure / protein turnover / substrate cycle

Résumé - Métabolisme énergétique au niveau du muscle chez le ruminant : influence de l'âge, de l'état nutritionnel et de l'état hormonal. Les dépenses énergétiques du muscle correspondent aux réactions biochimiques du métabolisme intermédiaire ou sont liées à la posture et à l'activité physique de l'animal. Les réactions métaboliques répondent à une grande variété de stimuli nutritionnels et hormonaux et sont souvent apparemment coordonnées; cependant, leur part dans les besoins énergétiques du muscle peut être faible comparée à celles de la locomotion et de la posture. Les réactions métaboliques comprennent le renouvellement des protéines, les transports ioniques et les cycles de substrats. Chez les jeunes ruminants la synthèse protéique musculaire est fortement influencée par le niveau d'alimentation mais les effets de ce dernier sur la dépense énergétique sont moins marqués. Chez l'adulte, la situation n'est pas claire. Le rôle de l'insuline chez les ruminants peut être différent de celui observé chez les monogastriques mais les hormones thyroïdiennes exercent une influence certaine. Le muscle du ruminant peut avoir un besoin en énergie élevé pour le transport de $\mathrm{Na}^{+}, \mathrm{K}^{+}$qui varie proportionnellement à la consommation totale d'oxygène

* Presented at the 5 th Conference on Nutrition and Feeding of Herbivores, INRA, Paris, 16-17 March, 1989 
en fonction du niveau d'alimentation. Le traitement par les hormones thyrö̈diennes et les catécholamines stimule le transport de $\mathrm{Na}^{+}, \mathrm{K}^{+}$et $\mathrm{Ca}^{2+}$. Le muscle est le siege de moins de cycles de substrats que le foie et chacun contribue pour 1 à 3\% seulement à la consommation d'oxygène. Plusieurs cycles de substrats sont sensibles à l'insuline mais des réponses plus importantes sont obtenues avec la thyroxine, l'épinéphrine et dans les conditions de stress; c'est pourquoi ils peuvent représenter une part importante de l'accroissement de la production de chaleur.

muscle squelettique / ruminant / dépense énergétique / turnover des protéines / cycle de substrats

\section{INTRODUCTION}

Total energy expenditure in animals is the sum of the contributions by individual tissues; these differ in metabolic activity per unit mass as identified from studies in vitro on cell respiration (Barcroft, 1946). This has been confirmed for ruminant tissues both in vitro (eg Gregg and Milligan, 1982a; McBride and Milligan, 1985a, 1985b) and in vivo (eg Bell et al, 1974; Webster et al, 1975; Oddy et al, 1984, Huntington et al, 1988). Thus liver and the gastrointestinal tract together comprise approximately $10 \%$ of the body weight of ruminant animals but account for nearly $50 \%$ of total oxygen consumption (Huntington et al, 1988; Huntington, 1990). In contrast, the skeletal musculature of sheep (approximately $30 \%$ of body weight) contributes a minor proportion (0.08-0.16) to whole body energy expenditure when animals are in confined laboratory conditions (table I).

There are many energy requiring processes which are common to all cells eg, those associated with protein turnover and ion movements. There are others which are specific to individual organs or tissues, eg ureogenesis in liver, reabsorption from kidney tubules, contractile activity in smooth and skeletal muscle. In particular the dynamics of muscle metabolism must be assessed against 2 major functions: the provision of mobility and the maintenance of the largest mobile store of reserve protein within the animal. Such functions are basic to all animals but the activities of specific reactions may differ between species and even within the same individual depending on prevailing physiological requirements.

Four major processes will be considered in detail:

- protein turnover;

- ion transport;

- substrate (futile) cycles;

- effects of posture and activity.

There is a considerable body of literature on energy requiring processes in rodent muscle but data for the farm species and man are more limited. It is recognised that real differences may exist between rodents and ruminants in the distribution of energetically expensive reactions in muscle but in order to provide a wide enough base data are included, where appropriate, from laboratory as well as commercial species.

\section{Comparisons in vitro and in vivo}

An additional concern with comparative data is the difference in the rates and controls of processes in vivo and in vitro. The rate of protein synthesis, for example, is lower with isolated muscle than in vivo (eg Palmer et al, 1981; Preedy and Garlick, 
Table I. Contribution of muscle energy expenditure in vivo to whole body oxygen consumption in sheep. a Based on $\mathrm{CO}_{2}$ exchange; $b$ Assumes whole body energy expenditure. Data based on hind limb studies corrected as follows. The contribution of muscle to leg energy expenditure assumed in same proportion as contribution to weight (62\%; Oddy et al, 1984). Leg muscle assumed representative of total musculature, which comprises $28 \%$ body weight (Palsson and Verges, 1952).

$\begin{array}{lcl}\text { Growing lambs } & 0.14-0.19 & \text { Harris } \text { et al, } 1989 \\ \text { Adult } & 0.12-0.15 & \text { Bird et al, 1981 a } \\ \text { Adult } & 0.21 & \text { Pethick et al, 1987b } \\ \text { Adult } & 0.12 & \text { Teleni } \text { et al, 1986a,b } \\ \text { Adult } & 0.17 & \text { Oddy et al, 1984 } \\ \text { Adult pregnant } & 0.14 & \text { Oddy et al, } 1984 \\ \text { Adult lactating } & 0.12 & \text { Oddy et al, } 1984\end{array}$

1983) although the magnitude of these differences varies (cf Palmer et al, 1981; Early et al, 1988b). Energy comparisons are more difficult as different muscles are used for ruminant studies in vitro (sternomandibularis or external intercostal) and in vivo (total or lower hind leg musculature). These preparations differ considerably in oxygen consumption per unit mass with those in vivo generally lower (table II). This may result in part from the contribution of bone, adipose tissue and skin in the arteriovenous preparations used in vivo, although both skin and bone are metabolically active as judged from rates of protein synthesis (eg Lobley et al, 1980; Attaix et al, 1988). In addition the different fibre-type composition of the muscles (Suzuki, 1971) leads to variations in metabolic rate, vascularity and protein synthesis (Lewis et al, 1984). Moreover, removal of the muscle from the body may result in dissociation of metabolic integration and uncoupled phosphorylation. Therefore comparisons from disparate data sources may not necessarily be valid.

\section{PROTEIN TURNOVER}

The term protein turnover encompasses the concomitant synthesis and breakdown of cell proteins (Waterlow et al, 1978). Both the anabolic and catabolic functions are extremely active and each may involve energy costs.

\section{Protein breakdown}

Earlier assumptions that intracellular proteolysis involves little or no energy cost now need to be revised. Gronostajski et al (1985) suggested that the maintenance of the acid $\mathrm{pH}$ of lysosomes requires ATP and the binding to protein of ubiquitin, which signals that protein degradation can proceed, also involves ATP (Ciechanover et al, 1984). In reticulocytes the inhibition of intracellular proteolysis effected a saving equivalent to 1 ATP per peptide bond hydrolysed (Siems et al, 1984; Rapoport et al, 1985). Recently Driscoll and Goldberg (1989) demonstrated that the proteasome (a multicatalytic endoproteinase complex) is activated 4-12-fold by ATP. Energyindependent proteolysis has, however, also been demonstrated in chick muscle (Wainberg et al, 1989). The ability of cells to use both energy-dependent and -independent systems to cleave peptide bonds means that "fixed" costs cannot be ascribed to proteolysis (see Summers et al, 1986); unfortunately our current know- 
Table II. Comparison of rates of oxygen consumption (mmol $\mathrm{O}_{2} / \mathrm{h} / \mathrm{kg}$ wet wt) by ruminant muscle in vitro and in vivo. 1 Assumes 23\% dry matter; 2 Included contribution from bone, skin and adipose tissue metabolism; some calculations based on $\mathrm{CO}_{2}$ exchanges.

\begin{tabular}{|c|c|c|}
\hline \multicolumn{3}{|l|}{$\begin{array}{l}\text { In vitro } 1 \\
\text { Sheep }\end{array}$} \\
\hline 2 weeks & 55.1 & Gregg and Milligan, $1982^{\circ}$ \\
\hline $2-5 \mathrm{yr}$ & 37.1 & Gregg and Milligan, 198 \\
\hline Cold & 31.7 & Gregg and Milligan, 1982 \\
\hline Warm & 21.5 & Gregg and Milligan, 198 \\
\hline Control $+T_{4}$ & 23.3 & McBride, 1986 \\
\hline Control + insulin & 25.5 & Early et al, $1988^{b}$ \\
\hline Adult & 12.3 & Barcroft, 1946 \\
\hline \multicolumn{3}{|l|}{ Cattle } \\
\hline $2-3$ weeks & 33.6 & Gregg and Milligan, 198 \\
\hline 7 months & 28.2 & Gregg and Milligan, 198 \\
\hline \multicolumn{3}{|l|}{ In vivo ${ }^{2}$} \\
\hline \multicolumn{3}{|l|}{ Sheep } \\
\hline Sw & 13.8 & Oddy and Lindsay, 1986 \\
\hline 5-9 months & 15.2 & Harris et al, $1989^{\circ}$ \\
\hline Adult & 15.4 & Bird et al, 1981 \\
\hline Adult & $8.4-19.1$ & Oddy et al, 1984 \\
\hline
\end{tabular}

ledge is insufficient to estimate the range of energy requirements in skeletal muscle from either laboratory or farm species.

\section{Protein synthesis}

In contrast to protein degradation there is an extensive literature which covers both whole body and muscle protein synthesis in chickens (eg MacDonald and Swick, 1981; Muramatsu et al, 1987), pigs (eg Garlick et al, 1976; Simon et al, 1978; Reeds et al, 1980; Sève et al, 1984), sheep (eg Buttery et al, 1975; Arnal et al, 1976; Davis et al, 1981; Pell and Bates, 1987; Attaix et al, 1988; Harris et al, 1989), goats (Muramatsu et al, 1988) and cattle (eg, Eisemann et al, 1986a, 1986b; Lobley et al, 1980, 1987). In all cases whole body protein synthesis exceeds protein intake by 2-4-fold (see Reeds and Lobley, 1980) and even at fasting total syn- thesis rates of $18 \mathrm{~g} / \mathrm{d} / \mathrm{kg}^{0.75}$ have been reported (see Lobley, 1988). Correlations were soon established between rates of whole body protein synthesis and heat production for adults of many species at maintenance intake (eg Garlick, 1980; Webster, 1981 ); with the release of $20-25 \mathrm{~kJ}$ of heat for every $g$ protein synthesis. This general relationship was also maintained in nutritional trials with young growing pigs (Reeds et al, 1980) and lambs (Harris et al, 1989) as well as with fattening cattle (Lobley et al, 1987); these experiments encompassed fasting animals and those at 3 $x$ maintenance (see Lobley, 1988). Such correlations led to the suggestion that protein synthesis comprised a larger proportion of heat production than could be considered on purely theoretical grounds (Webster, 1981). Estimation of the costs associated directly or indirectly with protein synthesis have been based on either the stoichiometric or empiral approach. 


\section{Stoichiometric approach}

It is generally accepted that, for mammalian tissues, protein synthesis requires 4 high-energy phosphate bonds per peptide unit (but see Summers et al, 1986). Two of these are involved in the activation of amino acids to the aminoacyl-tRNA and the other 2 are needed as GTP in attachment and translocation on the ribosome (see Buttery and Boorman, 1976). Yields of ATP per unit of metabolisable energy depend on the nutrient source; the values for glucose and acetate are 13.2 and $11.4 \mathrm{~mol}$ ATP/MJ ME, respectively (Baldwin, 1968; Lobley, 1986). Based on an average molecular weight of peptide amino acid of 110 , minimum theoretical costs are 2.8$3.2 \mathrm{~kJ}$ per $\mathrm{g}$ protein synthesis. In practice a wider range of values has been used and often the figure of $4.5 \mathrm{~kJ}$ per $\mathrm{g}$, as proposed by Webster (1981), is adopted. The rationale for this higher cost is that ancillary processes such as transport of amino acids into the cell, synthesis of RNA and DNA species, activation of ribosomal proteins and membrane-associated GTP hydrolysis are all involved in the synthesis of polypeptide bonds; these all require energy.

In practice the rates and energy requirements of these ancillary processes are poorly defined. Rates of amino acid transport into rat muscle in vivo have been reported by Banos et al (1973) to be between 16 (threonine) and 0.2 (aspartate) $\mathrm{mol} / \mathrm{min} / \mathrm{g}$ tissue. The energy costs of such transport have not been clarified; movements across the cell membrane are associated with concomitant transport of ions but the action of the membrane ATPase involves 3 sodium and 2 potassium ions per ATP hydrolysed (Mandel and Balaban, 1981). Based on the assumption that all amino acids are actively transported and that 2 molecules can be transferred per
ATP hydrolysed then total transport in rat muscle $\left(8.7 \mu \mathrm{mol}\right.$ amino acids $\mathrm{h}^{-1} \cdot \mathrm{g}^{-1}$; from Banos et al, 1973) would require 4.4 $\mu \mathrm{mol}$ ATP. For similar rats muscle protein synthesis rates of $6 \mu \mathrm{mol} \cdot \mathrm{h}^{-1} \cdot \mathrm{g}^{-1}$ have been reported (from Lewis et al, 1984); therefore amino acid transport might require an additional ATP per peptide bond synthesised.

Syntheses of the nucleic acid species also require energy (eg Sims et al, 1983) but the magnitude of macromolecule turnover and the associated thermal costs are still undefined, although regulation of ribosome number may be controlled primarily through alterations in breakdown rather than alterations in synthesis (Ashford and Pain, 1986).

\section{Empirical approach}

Attempts have been made to measure directly the costs associated with protein synthesis by use of the inhibitor of protein synthesis, cycloheximide which blocks peptide-bond formation. In isolated muscle from laboratory species the degree of inhibition in oxygen consumption varied from 0.14-0.23 (Reeds et al, 1985; McBride, 1986; Early et al, 1988b); while in 10-day chicks heat production declined by 0.33 in association with a 0.87 suppression of protein synthesis (Aoyagi et al, 1988). Aoyagi et al (1988) calculated that the energy cost of protein synthesis was $5.4 \mathrm{~kJ} / \mathrm{g}$ in the chick whereas the data of Early et al (1988b) on isolated sheep intercostal muscle preparations implies a value of $7.2 \mathrm{~kJ} / \mathrm{g}$ (calculations based on a calorific value for oxygen of $21 \mathrm{~J} / \mathrm{ml} \mathrm{O} \mathrm{O}_{2}$ ). Both values are higher than those adopted traditionally from stoichiometric considerations (vide supra) but the empirical technique may involve inhibition of other processes such as ion transport and nucleic acid turnover. Suggestions that the ATP costs of peptide 
bond formation may not be constant (see Summers et al, 1986) or that formation of amino-acyl t-RNA may not be rate-limiting and reformation of the free amino acid may occur with consequent energy penalties may also account in part for the differences in values reported.

\section{Muscle protein synthesis}

\section{Age}

The reduction in basal metabolic rate (expressed per unit metabolic body weight; $\mathrm{kg}^{0.75}$ ) which occurs as ruminants mature (Blaxter, 1962) is matched by declines in both muscle oxygen consumption (Gregg and Milligan, 1982b, c) and muscle protein synthesis (Arnal et al, 1976; Lobley et al, 1980; Oddy et al, 1987; Attaix et al, 1988). Direct measurements of changes in muscle energy expenditure and protein synthesis with age are not available, however, and comparisons between isolated studies may be confounded by environmental and behavioural factors.

\section{Nutrition}

Level of nutrition has a marked effect on protein synthesis in both the whole body (eg Lobley et al, 1987; Oddy et al, 1987; Harris et al, 1989) and in muscle (Oddy et al, 1987; Boisclair et al, 1988; Harris et al, 1989). Between fasting and ad libitum intake milk fed lambs increased the fractional rate of protein synthesis across the hind leg from 0.071-0.115/d (Oddy et al, 1987). In growing ruminants increases in feed intake from 0.6 to $1.8 \times$ maintenance caused corresponding increases in hind limb protein synthesis from 2.3 to $5.2 \mathrm{~g} / \mathrm{h}$ in cattle (Boisclair et al, 1988) and from 0.2 to 0.59 $\mathrm{g} / \mathrm{h}$ in lambs (Harris et al, 1989). For mature sheep, however, deprivation of feed for $40 \mathrm{~h}$ did not effect either hind-limb or whole body protein metabolism (Teleni et al, 1986) but fasting for 3 days (Pell et al, 1986) caused a marked decline in both whole body $(-28 \%)$ and hindquarter $(-50 \%)$ protein synthesis. The period of food withdrawal may therefore be critical, but similar contradictions have been observed for adult man where lack of response to overnight fast in whole body protein synthesis (eg Young et al, 1987; Melville et al, 1989) contrasts with changes in forearm (muscle) protein synthesis when intake is reduced (Cheng et al, 1985, 1987). Age-related differences have also been observed in rodents. In mature rats responses in muscle protein synthesis to either $12-42-h$ fasts or insulin are negligible (Baillie et al, 1988), but are quite marked in young animals (Garlick et al, 1983).

For ruminants the relationship between muscle protein synthesis and energy expenditure in response to intake is confused. In young cattle Boisclair et al (1988) observed similar changes in both parameters such that, if a value of $5.4 \mathrm{~kJ} / \mathrm{g}$ protein synthesis (Aoyagi et al, 1988) is applied, $25 \%$ of hind limb energy expenditure was attributable to protein synthesis. In contrast, Harris et al (1989) found in growing lambs that, unlike protein synthesis, hind leg oxygen uptake did not increase with intake; in consequence the contribution of protein metabolism to energy expenditure altered from 12 to $31 \%$ between 0.6 and $1.8 \times$ maintenance. In young lambs plasma $\mathrm{CO}_{2}$ production across the hind-limb increased by $16 \%$ (from Oddy et al, 1987) between fasting and supra-maintenance, compared with $62 \%$ in protein fractional synthesis rate; again the contribution of synthesis to energy expenditure apparently increased from 22 to $30 \%$ with intake. While effects of intake on adult ruminant hindquater oxygen uptake have generally 
been small, even when metabolisable energy intake has been varied 3-fold (Bird et al, 1981; Oddy et al, 1984; Teleni et al, 1986 ), changes of $35 \%$ in $\mathrm{CO}_{2}$ production were assumed in the calculations of Pell et al (1986) and these approximated to the changes in synthesis.

\section{Hormonal effects}

In ruminants the involvement of insulin in protein dynamics is controversial. Thus while insulin infusion will increase protein gain in fed pigs (Fuller et al, 1977) no effect is observed in lambs (Sumner and Weekes, 1983). In fasted lambs exogenous hormone appears to reduce both muscle protein breakdown and synthesis (Oddy et al., 1987); the latter observation is in contrast to findings in the fasted rat (Garlick et al, 1983; Reeds et al, 1985). In the experiments of Oddy et al (1987) exogenous hormone administration had no effect on protein synthesis in milk fed lambs but endogenous insulin concentrations may have been maximal for effects on protein dynamics in these animals (see Jepson et al, 1988). In growing sheep infused with insulin plus glucose the entry rate of phenylalanine across the hind limb was stimulated ( 17 vs $9 \mu \mathrm{mol} / \mathrm{h} / \mathrm{kg}^{0.75}$ ) although incorporation into gastrocnemius muscle protein and in vitro analysis of synthesis rates in external intercostal muscle were not significantly different from controls (Early et al, 1988a, b). Neither muscle oxygen uptake in vitro nor the proportion inhibited by cycloheximide were altered by insulin administration. Differences in both age and circulating concentrations of insulin existed between the studies of Oddy et al (1987) and Early et al (1988a) and may account in part for the apparently contradictory responses.

Isolated muscles analysed in vitro from sheep made hyperthyroid by injections of
$10 \mathrm{mg} / \mathrm{d}$ thyroxine did show increased protein synthesis (+ 35\%; McBride, 1986) and this also represented an increased proportion of oxygen uptake ( 23 vs $18 \%$, as assessed by cycloheximide inhibition). The proportion of cycloheximide-inhibited respiration also increased, albeit non-significantly, in incubated intercostal muscles from lactating cows treated with b-somatotropin compared with control tissue; muscle oxygen consumption also increased (0.53 vs $0.40 \mu \mathrm{O} \mathrm{O}_{2} \cdot \mathrm{mg}^{-1} \cdot \mathrm{h}^{-1}$; McBride et al, 1987). Administration of b-somatotropin also increased protein fractional synthesis rate of muscle in growing steers (Eisemann et al, 1989) and lambs (Pell and Bates, 1987). Epinephrine increases both whole body and muscle oxygen consumption (Lundholm and Svedmyr, 1965). In contrast the catecholamine depressed protein synthesis and increased amino acid oxidation in the hind limb of lambs (Oddy et al, 1987), observations compatible with the reduced rates of protein incorporation in muscles incubated with epinephrine (Wool, 1960). These actions of epinephrine probably also involve interactions between thyroid hormones and insulin status (vide infra).

\section{Summary}

Despite the apparent close association between rates of protein synthesis and heat production from a variety of nutritional trials it is obvious from experiments in which individual hormones have been varied that the contribution made by protein metabolism to muscle energy expenditure can increase or decrease in response to prevailing physiological or pharmacological conditions. Perhaps the most perplexing question at present relates to the apparent contradiction between the large increases in protein synthesis which accompany ac- 
company extra intake in ruminants and the lack of any simple relationship with insulin (as is the case for growing monogastric animals). Possibly this indicates that regulation of protein synthesis in ruminants may involve a greater role for other hormones or growth factors.

Based on stoichiometric values and the use of inhibitors with incubated muscles the contribution of protein synthesis to energy expenditure in muscle under normal conditions would appear to be 15-25\%. Extra costs associated with protein breakdown cannot at present be quantified although the value is unlikely to exceed 5$10 \%$.

\section{ION TRANSPORT}

Movements of ions into, out of and across the cell represent a major metabolic function and are involved in transport of substrates, regulation of hormone action (Rosenthal et al, 1988) and the control of muscle contraction.

\section{$\mathrm{Na}^{+}, \mathrm{K}^{+}$transport}

Most attention has focussed on the $\mathrm{Na}^{+}$, $\mathrm{K}^{+}$-ATPase of the membrane where the movement of every $3 \mathrm{~mol}$ of $\mathrm{Na}^{+}$out of and $2 \mathrm{~mol}$ of $\mathrm{K}^{+}$into the cell involves the hydrolysis of one mol of ATP (Mandel and Balaban, 1981). The process is blocked by the cardiac glycoside ouabain and this has enabled the contribution to cell respiration to be studied under a wide range of conditions, but exclusively in vitro (eg Whittam, 1961; Ismail-Beigi and Edelman, 1971; Gregg and Milligan, 1982a, b, c).

The changes in heat loss or oxygen uptake induced by ouabain for muscle tissues have been very variable. Several groups have claimed that $20-50 \%$ of aerobic respiration is required for maintenance of $\mathrm{Na}^{+}, \mathrm{K}^{+}$gradients while others have suggested that values of $6-12 \%$ are more realistic (table III). The reasons for these differences are controversial; preparations in vitro are dependent on minimising tissue damage and cut surfaces, establishing appropriate incubation media and ensuring that oxidative phosphorylation remains tightly coupled (for discussion, see Chinet et al, 1977; Gregg and Milligan, 1982b; Chinet, 1990). Species differences may also exist. Fortunately, many of the studies conducted with ruminant muscle are based on response analyses so that effects of nutritional, endocrinological and physiological stimuli will have qualitative importance even if some revision of their quantitative nature needs to be applied.

\section{Age}

As with protein synthesis, $\mathrm{Na}^{+}, \mathrm{K}^{+}$-ATPase activity declines as the animal matures (Gregg and Milligan, 1982a, c) such that it remains a relatively constant fraction of cell energy expenditure. This degree of association between cell respiration and key processes such as protein synthesis and ion transport has been extended into the concept of linked mechanisms and integrated cell responses (Webster, 1981).

\section{Intake and hormonal effects}

Direct studies on the effects of intake on $\mathrm{Na}^{+}, \mathrm{K}^{+}$-ATPase have not been reported. In lactation, however, intake is increased considerably and was doubled between the dry and lactating state for ewes offered chaffed oaten hay by Oddy et al (1984). This was accompanied by a $35 \%$ increase in hind leg oxygen consumption, an almost similar increase to the oxygen uptake observed for muscles in vitro between lactat- 
Table III. Na+, K+-ATPase contribution to muscle energy expenditure in vitro. All values based on use of cardiac glycoside ouabain. By $\mathrm{O}_{2}$ consumption except for ${ }^{*}$ by microcalorimetry.

Muscle $\quad \%$ Contribution

Rat soleus

Mouse soleus

Rat diaphragm

Sheep intercostal

Mouse soleus

Hamster diaphragm

Sheep intercostal

Lamb intercostal

Rat pectoralis

Sheep sternomandibularis

Cattle sternomandibularis

Rat diaphragm
$\%$ Contribution ing and dry ewes by Gregg and Milligan $(1982 a, c)$. In this latter study, however, ouabain-sensitive respiration remained a fixed proportion of muscle oxygen uptake. Similarly, Early et al (1988b) reported that insulin altered neither the contribution $(23 \%)$ of $\mathrm{Na}^{+}, \mathrm{K}^{+}-\mathrm{ATP}$ ase nor the total oxygen consumption in isolated sheep muscle.

Alterations in the relative activity of iontransport do occur however under conditions of stress. Muscle from sheep maintained in the cold $\left(1^{\circ} \mathrm{C}\right)$ has a greater $(50 \%)$ oxygen consumption than that from animals housed at $25{ }^{\circ} \mathrm{C}$ and $70 \%$ of the extra uptake is attributable to $\mathrm{Na}^{+}, \mathrm{K}^{+}$ATPase activity (Gregg and Milligan, 1982a). In consequence the proportion of energy expenditure attributable to the process increased from 29 to $45 \%$. Cold stress is associated with changes in thyroid hormone and catecholamine status (Christopherson et al, 1978) and in hyperthyroid sheep (given exogenous $T_{4}$ ) there was a $50 \%$ stimulation of ouabainsensitive respiration (McBride, 1986) al- though muscle oxygen uptake was similar to that in control animals. Curiously there were concomitant increases in muscle protein synthesis as a result of $\mathrm{T}_{4}$ administration (McBride, 1986) such that the two processes together accounted for $49 \%$ of tissue respiration compared with only $36 \%$ for control animals. This result may be misleading as ouabain, in a manner analogous to cycloheximide, may alter other processes including protein synthesis by direct or indirect means. If the observations are additive, however, then other thermogenic processes must decline in the presence of $\mathrm{T}_{4}$.

\section{Calcium}

$\mathrm{Ca}^{2+}$ movements are vital for the execution of muscle contraction but even in resting muscle $7 \%$ of energy expenditure may be attributed to the activity of the sarcoplasmic reticulum $\mathrm{Ca}^{2+}$-ATPase (Hasselbach and Oetliker, 1983). Translocation of $\mathrm{Ca}^{2+}$ across other muscle membranes such as 
the T-tubules, sarcolemma (Michalak et al, 1984) and mitochondria (Mickelson and Marsh, 1980) may account for a further $13 \%$ (cited by Summers et al, 1986).

Again, thyroid status influences $\mathrm{Ca}^{2+}$ transport and in hyperthyroid animals increases in total enzyme and maximal activity occur for tonic muscles (Kim et al, 1982) whereas in the hypothyroid state increases in the coupling of $\mathrm{Ca}^{2+}$ transport across the sarcolemma counteract the effect of lowered ATPase activity (Simonides and Van Hardeveld, 1985). Current estimates of the contribution of $\mathrm{Ca}^{2+}$ movements to muscle oxygen consumption are approximately $10 \%$ (Summers et al, 1986; Chinet, 1990).

\section{General}

Based on recent studies with ruminant muscle preparations in vitro, cell bioenergetics include a value of $18-23 \%$ for $\mathrm{Na}^{+}$, $\mathrm{K}^{+}$-ATPase which, together with $10 \%$ for $\mathrm{Ca}^{2+}$ transport, would give an ion-transport contribution of approximately $30 \%$ to energy expenditure. These values may increase under conditions of severe stress and in particular where thyroid hormone status is elevated.

\section{SUBSTRATE CYCLES}

Reversible reactions which are catalysed by 2 different enzymes (or enzyme complexes) and involve the expenditure of energy are termed substrate cycles; the old terminology of "futile cycles" has now fallen into disuse. The simultaneous synthesis and breakdown of metabolites under the control of separately regulated enzymes (fig 1) affords several advantages for cellular mechanisms. Such reactions contribute to heat production required to maintain homeothermy and provide a flexible response system in situations where increased energy dissipation is necessary, eg non-shivering thermogenesis. In addition, accumulation of products which may exert either harmful or regulatory effects on other cellular processes can be avoided through the action of substrate cycles. Furthermore, because the rate of cycling can be large compared with the flow of substrates through a metabolic sequence small changes in the rate of the forward or back reaction can induce considerable changes in net flux. The system is thus very sensitive to regulators and in consequence substrate cycles are invariably found as the key reactions of metabolic sequences and under hormonal control (Newsholme and Crabtree, 1976); this may constitute their primary role.

The list of possible substrate cycles is extensive (Katz and Rognstad, 1976; Newsholme and Crabtree, 1976; Rabkin and Blum, 1985) but in most cases the contribution of any individual reaction to cell energy requirements is small. The most notable exception to this is protein turnover (which simultaneously involves synthesis and breakdown under the action of different enzyme complexes). Nevertheless in liver other substrate cycles may contribute $19-28 \%$ of ATP hydrolysis (Rabkin and Blum, 1985). There are considerable technical difficulties associated with measurement of such cycles in that often dual tracers are required to obtain true values (Katz and Rognstad, 1976; Challis et al, 1984b; Crabtree and Lobley, 1988); in consequence many earlier values may need to be reassessed (eg Clark et al, 1973).

Fewer substrate cycles exist in muscle (fig 1) and quantitative data are limited, especially for the larger species. Thus for the triglyceride: fatty acid cycle no values are available, although considerable changes 


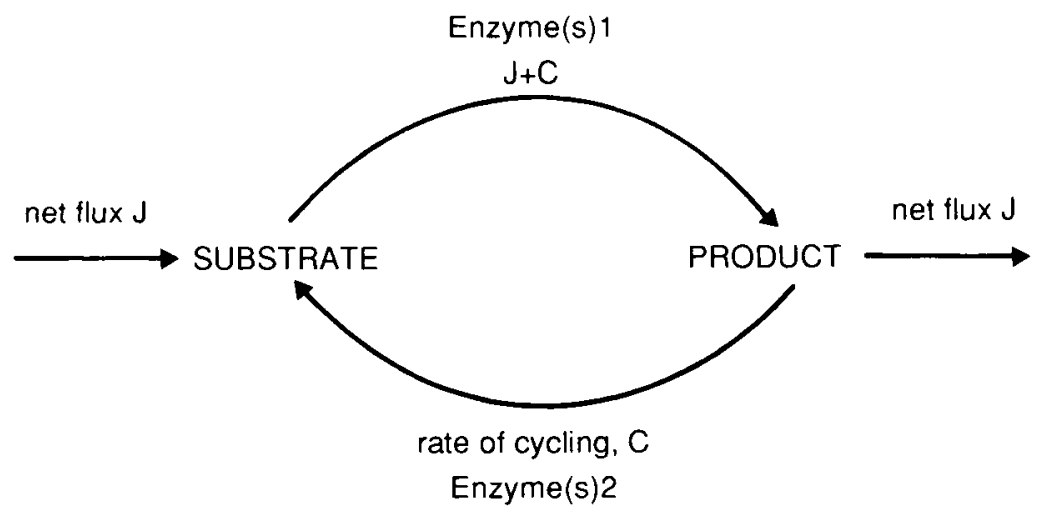

$\frac{\text { Substrate }}{\text { Product }}$

1. glycogen

glucose 1-phosphate

2. triacylglycerol

fatty acid

3. fructose 6-phosphate

fructose 1,6-bisphosphate

4. acetate

acetyl COA
Enzyme(s) $\frac{1}{2}$

phosphorylase

glucose -1. phosphate

uridyltransferase + glycogen

synthase

triacylglycerol lipase

fatty acyl CoA synthetase

+ esterification enzyme complex

phosphofructokinase

tructose 1.6-bisphosphatase

acetyl COA synthetase

acetyl CoA hydrolase
8

ATP costs

of cycling

1

Fig 1. Substrate cycles in skeletal muscle. Each turn of the cycle causes hydrolysis of ATP.

in the rates of reesterification/deesteridication occur during the lactation curve in dairy goats (Dunshea and Bell, 1989). While much of this activity may be in white adipose tissue (Brooks et al, 1982) the potential for this cycle does exist in muscle.

\section{Acetate-acetyl CoA cycle}

Acetate is a major fuel for ruminant muscle (Jarrett et al, 1976) and enters both ana- bolic and catabolic sequences as acetylCoA. The CoA ester is however a potent regulator of many reactions and in situations where aceyl-CoA cannot effectively enter an anabolic or catabolic sequence the ability to effect hydrolysis to acetate provides an important safety measure. The hydrolase enzyme involved has been shown to be especially active in the cytoplasm of rat hepatocytes (Rabkin and Blum, 1985; Jessop et al, 1986) but additional observations in vivo have been 
made in sheep muscle (Pethick et al, 1981) and refined and extended by Crabtree et al (1987). Rates of muscle acetylCoA hydrolysis were equivalent to 0.4 mmol ATP $\cdot \mathrm{kg}^{-1} \cdot \mathrm{h}^{-1}$, equivalent to $2 \%$ of muscle energy expenditure (Harris et al, 1989). Under the experimental conditions adopted by Crabtree et al (1987), ie mature wethers fed to maintenance on grass pellets, doubling the acetate supply to the animal did not produce a significant stimulation of this substrate cycle in muscle.

The studies of Pethick et al (1981) and Crabtree et al (1987) provide the only data to date on substrate cycles in ruminant muscle and for further information it is necessary to use studies on other species, usually rodents.

\section{Glycogen/glucose-1-phosphate (G/GIP) cycle}

This cycle regulates the synthesis and breakdown of glycogen, the major internal fuel store in muscle and sensitive hormonal regulation is essential especially for phasic muscles. Under basal conditions GIP production exceeds glycogen synthesis and net flux (respectively $0.74,0.54$ and -0.20 glucosyl equivalents $\cdot \mathrm{g}^{-1} \cdot \mathrm{h}^{-1}$ ) in isolated rat epitrochlearis muscle (Challiss et al, 1987). The direction of net flux is reversed through the addition of insulin; this is achieved by a decrease in glycogen breakdown and an increase in synthesis ( 0.38 and 0.97 glucosyl equivalents $/ g / h$ respectively). If applied to the in vivo state this would suggest that even in the fed condition cycling still occurs. The measured rates of glycogenolysis represent < $1 \%$ of the maximal activity of phosphorylase present in muscle and the low expression of potential cycle activity under basal or normal physiological conditions is typical for the majority of substrate cycles. For the G/GIP cycle the simultaneous stimulation of glycogen synthetase and inhibition of phosphorylase by insulin is associated, in part at least, by changes in the activity of protein phosphatases-1 and 2 which regulate the phosphorylation status of the two enzymes (Tung et al, 1985).

Epinephrine can induce marked changes $(x 15)$ in rates of glycogen breakdown but the major effects are observed only under conditions $(x 100)$ in excess of normal unstressed physiological catecholamine concentration ( $\approx 1 \mathrm{nM}$; Buhler et al, 1978). Responses at lower (10 nM) epinephrine concentrations can be induced, however, if thyroid hormones are present (Challiss et al, 1987) and this is consistent with the general hypothesis that muscle sensitivity to catecholamines is enhanced by triodothyronine (Williams and Lefkowitz, 1983). Indeed the greater control appears exerted through regulation of breakdown (ie phosphorylase activity), as the post-exercise increase in muscle glycogen synthesis observed even in the fasted condition for man (Hermansen and Vaage, 1977) and rat (Davis et al, 1986) may be associated more with reduced glycogenolysis rathen than a stimulation of glycogen synthase (Challiss et al, 1987). In consequence this cycle is unlikely to contribute to the increase in oxygen consumption reported for the post-exercise condition (Gleeson et al, 1982; Gaesser and Brooks, 1984).

As it is the reverse reaction, ie glycogen synthesis, which provides the thermic response of this cycle obviously in situations such as stress or exercise the extra heat production will not include an additional contribution through the activity of glycogen synthase. Under basal or normal physiological conditions the contribution to muscle oxygen consumption will be $1-1.5 \%$ (from Challiss et al, 1987). This minor role in oxygen consumption should not detract from the importance in regulation of the internal fuel source of glycogen which will be 
important for other thermogenic reactions. Such an example is in starvation where muscle glycogen synthesis is enhanced (Challiss et al, 1987).

\section{Fructose 6-phosphate/fructose-1,6-bis- phosphate (F6P/F16bP)}

This is perhaps the most studied substrate cycle in muscle and it occupies a key role in glycolysis and gluconeogenesis. Regulation of phosphofructokinase in glycolytic flux is well established but the activity of fructose bisphosphatase is also acutely sensitive to hormonal regulation in a similar manner to the G/GIP cycle. This is to be expected as they are components of the same glycogenolytic sequence.

Most of the available information comes from rat muscle studies in vitro and the rates of both the forward and reverse reactions are increased $(x 2)$ by insulin (Challiss et al, 1984a). Epinephrine (10 $\mathrm{nM})$ is a major regulator of the fructose biphosphatase and can increase the reverse reaction $x 3$ without a corresponding increase in glycolytic rate (Challiss et al, 1984a, b). During starvation the rate of formation of F16BP is unaltered while conversion back to F6P is reduced to one-third (Challiss et al, 1985b).

Control of cycling again involves a major interaction, between epinephrine and thyroid status. Muscles from hyperthyroid rats incubated in the presence of insulin do not show changes in either the glycolytic or cycle rate compared with control rats but in the presence of $10 \mathrm{nM}$ epinephrine the reverse reaction doubles (Challiss et al, 1985a). Similar effects are found with muscles from acutely exercised (90 min) rats when the cycle rate increased from 0.20 to $0.53 \mu \mathrm{mol} \cdot \mathrm{h}^{-1} \cdot \mathrm{g}^{-1}$. The experiment (Challiss et al, 1985a) included an incubation period for the muscles in vitro so that in- creases in cycle rate may have been even greater immediately post-exercise.

Unlike the G/GIP cycle, therefore, F6P/ F16bP does contribute to post-exercise oxygen consumption. The rates of cycling reported in the literature range from $0.2-0.7$ $\mu \mathrm{mol} / \mathrm{h} / \mathrm{g}$, under basal conditions (with insulin, present), and this would represent $0.2-1.0 \%$ of oxygen consumption.

In stress conditions the contribution may rise to $2-3 \%$ of total energy expenditure but would represent a much greater proportion of the heat increment associated with the trauma. This is shown most dramatically in pigs which suffer from the malignant hyperthermia syndrome (Berman et al, 1970) and where either stress (eg transport to market) or halothane anaesthesia induce a rapid increase in body temperature, muscle rigor and often death. Most of the extra thermogenesis is muscle-derived and involves the F6P/F16bP cycle. In nonstressed animals the rate of cycling varies from $0.3-3.0 \mathrm{mmol} \cdot \mathrm{h}^{-1} \cdot \mathrm{kg}^{-1}$ muscle and would account for $0.3-3.0 \%$ of tissue ATP hydrolysis (from Clark et al, 1973). Non sensitive pigs exhibit no change in cycle rate during halothane administration but sensitive animals increase arteriovenous blood temperatures by $1.5^{\circ}$ and increase the rate of cycling 10-fold (Clark et al, 1973). This stimulation of the reverse reaction may be underestimated by as much as 4-fold due to the single isotope method used (see Katz and Rognstad, 1976) and, based on a blood flow of $70 \mathrm{ml} \mathrm{min}{ }^{-1} \cdot \mathrm{kg}^{-1}$ muscle for the anaesthetised animal, the contribution to heat increment by the cycle may be $7-30 \%$. This is an extreme case but indicates the potential for heat production which exists for substrate cycles and may be invoked under stress conditions.

Regulation of the F6P/F16bP cycle may involve another substrate cycle, fructose 6phosphate:fructose 2,6-biphosphate(F6P: $\mathrm{F} 26 \mathrm{bP}$ ). This sytem is active in liver (see 
van Schaftingen, 1987) and may provide the oscillations which allow communication (and thus control) between $\mathrm{F} 16 \mathrm{bP}$ and phosphofructokinase (see Crabtree and Newsholme, 1985). In rat muscle, insulin and epinephrine increase the concentration of F26bP, but the potential contribution to control of phosphofructokinase is approximately $10 \%$ that of F16bP (see van Schaftingen, 1987). This additional control cycle may therefore be of less importance in muscle compared with liver but as yet this has not been determined for ruminant species.

\section{Summary}

It must be remembered that both protein and lipid turnover represent substrate cycles as defined and both make substancial contributions to energy metabolism in the whole animal and muscle. For the other known substrate cycles, while it is difficult to extrapolate studies from rodents and preparations in vitro to ruminant muscle in vivo, probably a value of $5-8 \%$ can be ascribed, on the basis of current knowledge, as their contribution to heat production under normal conditions.

\section{POSTURE AND ACTIVITY}

Increases in physical activity elevate both whole animal and muscle energy expenditure. Exercise, even at moderate levels, can stimulate oxygen uptake by the hind limbs of sheep and cattle by 2-10-fold (eg Bird et al, 1981; Pethick et al, 1987) and this is accompanied by increases in blood flow. Most measurements of hind-limb metabolic activity referred to in this review have been derived, however, from animals which have been restrained to the standing or lying condition plus minor move- ments. Nevertheless, even these postural changes can be energetically expensive and the costs of standing in cattle have been variously reported as 4.6 to 17 $\mathrm{J} \cdot \mathrm{min}^{-1} \cdot \mathrm{kg}^{-1}$ body weight (Forbes et al, 1927; Hall and Brody, 1933; Ku-Vera et al, 1989). A recent systematic study conducted by Brockway (1987; unpublished observations) involving 20 growing steers and heifers and encompassing several thousand 30-min measurements during respiration chamber confinement yielded a value of $25 \mathrm{~J} \cdot \mathrm{min}^{-1} \cdot \mathrm{kg}^{-1}$ live weight.

The importance of activity to overall (and muscle) heat production is illustrated in figure 2. Calorimetric studies often yield data which show considerable daily interand intra-animal variation. The data in figure 2 are from 2 animals of similar breed, age and weight, fed the same quantity of ration and measured at the same time. Total daily heat production differed by $8 \mathrm{MJ}$, but when adjusted for the difference in time spent standing (7 vs $14 \mathrm{~h}$ ), "corrected" heat productions were very similar. Removel of postural effects from both whole animal and muscle oxygen uptake measurements will be essential for assessment of changes due to metabolic activity.

Diet quality and quantity can influence activity patterns (Wenk and Van Es, 1976) and in the study of Oddy et al (1984) marked differences in hind leg oxygen consumption for non-pregnant, non-lactating ewes were observed depending on whether the animals were fed lucerne or oaten

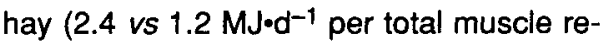
spectively); these may involve metabolic effects but more likely are postural differences.

The value of $25 \mathrm{~J} \cdot \mathrm{min}^{-1} \mathrm{~kg}^{-1}$ live weight may not be applicable to all farm species (eg pigs, $132 \mathrm{~J} / \mathrm{min} / \mathrm{kg}$; Hornicke, 1970; sheep, $8 \mathrm{~J} / \mathrm{min} / \mathrm{kg}$; Hall and Brody, 1933; $37 \mathrm{~J} / \mathrm{min} / \mathrm{kg}$, Brockway et al, 1969) but if all this expenditure is attribuable to muscle 


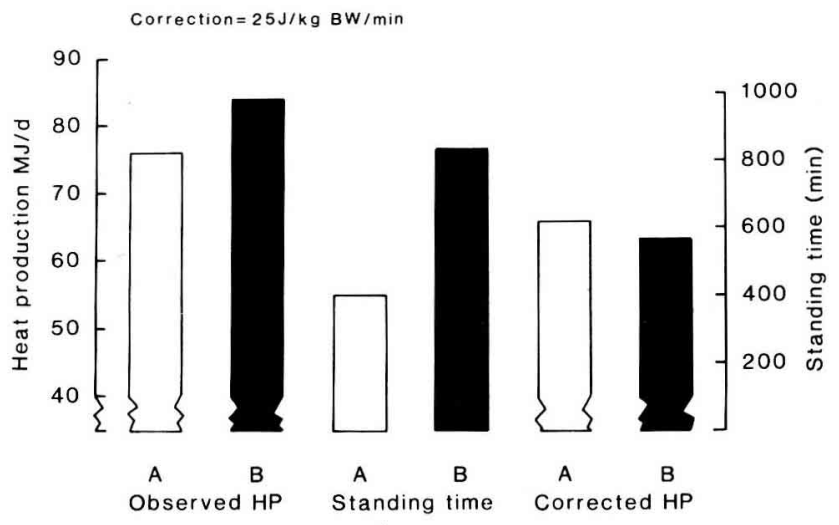

Fig 2. Effect of standing on energy expenditure in cattle. Two Hereford $x$ Friesian heifers $(A, 570 \mathrm{~kg}$; $B, 590 \mathrm{~kg}$ ) offered same diet quantity $(1.8 \times$ maintenance). Observed heat production corrected for standing time (25 J/kg body wt/min; Brockway, 1987). Data from Mollison and Brockway (unpublished).

then the oxygen uptake would be $3-6 \mathrm{ml}$ $\mathrm{O}_{2} / \mathrm{min} / \mathrm{kg}$ muscle for the standing ruminant. In the experiment of Harris et al (1989) the lambs stood for $\approx 50-70 \%$ of the experimental period and therefore 30 $50 \%$ of hind-limb oxygen consumption could be attributed to posture requirements even for animals restricted within a metabolism cage-respiration hood system.

\section{Summary}

Energy requirements for cellular processes can be relatively minor compared with effects of posture and activity in vivo. Intake or exogenous hormone treatment may alter the activity status and mask or confound the effects of such manipulations on metabolic energy expenditure. Furthermore, although allocation of $30-50 \%$ towards muscle oxygen requirement in vivo may be appropriate, such additions should not be applied in the situation in vitro where usually muscles are either relaxed or maintained at resting length.

\section{CONCLUSIONS}

Current knowledge would suggest that only $40-60 \%$ of energy requirements for skeletal muscles can be attributed to the metabolic demands of protein turnover, ion-transport and substrate cycles (fig 3). The separation of these 4 components is to some extent arbitrary in that considerable interactions between the processes exist. Transport of amino acids, with associated ion movements, interacts with protein synthesis; increased metabolite flow required during exercise also involves stimulation of ion-transport; catabolism of amino acids during prolonged, strenuous activity will alter rates of protein turnover; cation movements, especially $\mathrm{Ca}^{2+}$, are crucial to metabolic regulation, including control of certain substrate cycles. Because of these interactions it is possible for under- (or over-) estimation of energy costs to have been made both in vivo and in vitro for each process. A considerable portion of oxygen consumption measured in vivo may be a consequence of postural 


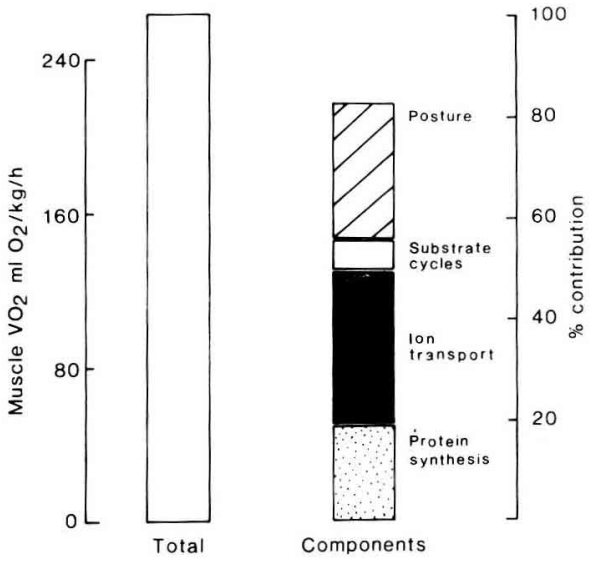

Fig 3. Contribution of specific processes to sheep hindquarter energy expenditure in vivo. Data based on total oxygen uptake across hindleg muscle of $35-\mathrm{kg}$ lambs at maintenance intake (from Harris et al, 1989).

status but this will have a smaller value in vitro. The proportional contribution of protein synthesis to oxygen requirements in vivo and in vitro are similar, which suggests that other processes may occur in vitro to "replace" that for activity in the whole animal. Certain studies, eg ion transport and substrate cycles, have been largely or wholly restricted to incubated muscles and there is an urgent need for these to be extended to the whole animal. By sensible integration of studies in vivo and in vitro the current anomalies in the balance-sheet for muscle energy expenditure can be eliminated.

\section{REFERENCES}

Aoyagi Y, Tasaki I, Okumura Jl, Muramatsu T (1988) Energy costs of whole-body protein synthesis measured in vivo in chicks. Comp Biochem Physiol 91A, 765-768

Arnal M, Ferrara M, Fauconneau G (1976) Synthèses protéqques in vivo pendant le déve- loppement de quelques muscles de l'agneau. In: Proc Int Symp Nuclear Technique in Animal Production and Health as Related to the Soil Plant System. IAEA, Vienna, 393-401

Asano Y, Liberman VA, Edelman IS (1976) Thyroid thermogenesis relationships between $\mathrm{Na}^{+}, \mathrm{K}^{+}$-ATPase activity in rat skeletal muscle. J Clin Invest 57, 368-379

Ashford AJ, Pain VM (1986) Insulin stimulation of growth in diabetic rats. Synthesis and degradation of ribosomes and total tissue protein in skeletal muscle and heart. $J$ Biol Chem 261, 4066-4070

Attaix D, Aurousseau E, Manghebati A, Arnal M (1988) Contribution of liver, skin and skeletal muscle to whole body protein synthesis in the young lamb. Br J Nutr 60, 77-84

Baillie AGS, Maltin CA, Garlick PJ (1988) The effect of fasting and insulin infusion on muscle protein synthesis in immature and adult rats. Proc Nutr Soc 47, 114A

Baldwin RL (1968) Estimation of theoretical calorific relationships as a teaching technique: a review. J Dairy Sci 51, 104-111

Banos G, Daniel PM, Moorhouse SR, Pratt OE (1973) The movement of amino acids between blood and skeletal muscle in the rat. $J$ Physiol (London) 235, 459-475

Barcroft J (1946) Researches on Pre-Natal Life. Blackwell Scientific Publications, Oxford, 97103

Bell AW, Gardner JW, Thompson GE (1974) The effects of acute cold exposure and feeding on volatile fatty acid metabolism in the hind leg of the young ox. Br J Nutr 32, 471477

Berman MC, Harrison GG, Bull AB, Kench JE (1970) Changes underlying halothaneinduced malignant hyperpyrexia in Landrace pigs. Nature (Lond) 225, 653-655

Bird AR, Chandler KD, Bell AW (1981) Effects of exercise and plane of nutrition on nutrient utilisation by the hind limb of the sheep. Aust $J$ Biol Sci 34, 541-550

Biron R, Burger A, Chinet A, Clausen T, DuboisFerriere R (1979) Thyroid hormones and the energetics of active sodium-potassium transport in mammalian skeletal muscles. $J$ Physiol (Lond) 297, 47-60

Blaxter KL (1962) The Energy Metabolism of Ruminants. Hutchinson, London 
Boisclair Y, Bauman DE, Bell AW, Dunshea FR (1988) Muscle protein synthesis and wholebody $\mathrm{N}$ balance in fed and underfed steers. FASEB J 2, A848

Brockway JM (1987) Influence of activity. Rowett Res Inst Rep

Brockway JM, Pullar JD, McDonald JD (1969) Direct and indirect calorimetric techniques for the evaluation of the energy expenditure of standing and lying sheep. In: Energy Metabolism of Farm Animals (Blaxter KL, Thorbek G, Kielanowski J, eds) Oriel, Newcastle upon Tyne, 423-427

Brooks B, Arch JS, Newsholme EA (1982) Effects of hormones on the rate of the triacylglycerol/fatty acid substrate cycle in adipocytes and epididymal fat pads. FEBS Lett $146,327-330$

Buhler HU, Da Prada M, Haefely W, Picotti GB (1978) Plasma adrenaline, noradrenaline and dopamine in man and different animal species. J Physiol (Lond) 276, 311-320

Buttery PJ, Beckerton A, Mitchell RM, Davies K Annison EF (1975) The turnover rate of muscle and liver protein in sheep. Proc Nutr Soc 34, 91A

Buttery PJ, Boorman KN (1976) The energetic efficiency of amino acid metabolism. In: Protein Metabolism and Nutrition (Cole JA, Boorman KN, Buttery PJ, Lewis D, Neal RJ, Swan $\mathrm{H}$, eds) Butterworths, London, 197-215

Challiss RAJ, Crabtree B, Newsholme EA (1987) Hormonal regulation of the rate of the glycogen/glucose-1-phosphate cycle in skeletal muscle. Eur J Biochem 163, 205-210

Challiss RAJ, Arch JS, Newsholme EA (1985b) Starvation for $24 \mathrm{~h}$ decreases fructose 6phosphate/fructose 1,6-bisphosphate substrate cycling in skeletal muscle. Biochem Soc Trans 13, 269-270

Challiss RAJ, Arch JS, Newsholme EA (1985a) The rate of substrate cycling between fructose-6-phosphate acid fructose bisphosphate in skeletal muscle from cold-exposed hyperthyroid or acutely exercised animals. Biochem J 231, 217-220

Challiss RAJ, Arch JS, Newsholme EA (1984a) The rate of substrate cycling between fructose-6-phosphate and fructose 1,6,bisphosphate in skeletal muscle. Biochem $J$ 221, 153-161
Challiss RAJ, Arch JRS, Crabtree B, Newsholme EA (1984b) Measurement of the rate of substrate cycling between fructose-6phosphate and fructose 1,6-bisphosphate in skeletal muscle by using a single-isotope technique. Biochem J 223, 849-853

Cheng KN, Dworzak F, Ford GC, Rennie MJ, Halliday D (1985) Direct determination of leucine metabolism and protein breakdown in humans using $L-\left[1-{ }^{13} \mathrm{C},{ }^{15} \mathrm{~N}\right]$ leucine and the forearm model. Eur J Clin Invest 15, 349-354

Cheng KN, Pacy PJ, Dworzak F, Ford GC, Halliday $D$ (1987) Influence of fasting on leucine and muscie protein metabolism across the human forearm determined using $L-\left[1-{ }^{13} \mathrm{C}\right.$, ${ }^{15} \mathrm{~N}$ jeucine as the tracer. Clin Sci 73, 241246

Ciechanover A, Finley D, Varshausky A (1984) The ubiquitin-mediated proteolytic pathway and mechanisms of energy-dependent intracellular protein degradation. $J$ Cell Biochem 24, 27-53

Chinet A (1990) Les composantes des dépenses énergétiques et la régulation du métabolisme énergétique au niveau cellulaire. Reprod Nutr Dev 30, 1-11

Chinet A, Clausen T, Girardier L (1977) Microcalorimetric determination of energy expenditure due to active sodium-potassium transport in the soleus muscle and brown adipose tissue of the rat. J Physiol 265, 43-61

Christopherson RJ, Thompson JR, Hammond VA, Gills GA (1978) Effects of thyroid status on plasma adrenaline and noradrenaline concentrations in sheep during acute and chronic cold exposure. Canad J Physiol Pharmacol 56, 490-496

Clark JG, Williams $\mathrm{CH}$, Pfeifer WF, Bloxham DP, Holland PC, Taylor CA, Lardy HA (1973) Accelerated substrate cycling of fructose-6phosphate in the muscle of malignant hyperthermic pigs. Nature 245, 99-101

Crabtree B, Marr SA, Anderson SE, MacPae JC (1987) Measurement of the rate of substrate cycling between acetate and acetyl-CoA in sheep muscle in vivo. Biochem $J 243,821$ 827

Crabtree B, Lobley GE (1988) Measuring metabolic fluxes in organs and tissues with single and multiple tracers. Proc Nutr Soc 47, 353364 
Crabtree BF, Newsholme EA (1985) A quantitative approach to metabolic control. Curr Top Cell Regul 25, 21-76

Davis SR, Barry TN, Hughson GA (1981) Protein synthesis in tissues of growing lambs. $B r$ J Nutr 46, 409-419

Davis TA, Klahr S, Tegtmeyer ED, Osborne DF, Howard TL, Karl IE (1986) Glucose metabolism in epitrochlearis muscle of acutely exercised and trained rats. Am J Physiol 250, E137-E143

Driscoll J, Goldberg AL (1989) Skeletal muscle proteasome can degrade proteins in an ATPdependent process that does not require ubiquitin. Proc Natl Acad Sci USA 86, 787-791

Dunshea FR, Bell AW (1989) Non-esterified fatty acid recycling (re-esterification) and lipid mobilisation in goats during early lactation. In: Energy Metabolism of Farm Animals (van der Honing $\mathrm{Y}$, Close WH, eds) Eur Assoc Anim Prod Publ 43; Pudoc, Wageningen, 119-122

Early RJ, McBride BW, Ball RO (1988a) Phenylalaline metabolism in sheep infused with glucose plus insulin. I. Effects on plasma phenylalanine concentration, entry rate and utilisation by the hindlimb. Canad J Anim Sci 68, 711-719

Early RJ, McBride BW, Ball RO (1988b) Phenylalanine metabolism in sheep infused with glucose plus insulin. II. Effects on in vivo and in vitro protein synthesis and related energy expenditures. Canad J Anim Sci 68, 721-730

Eisemann JH, Hammond AC, Bauman DE, Reynolds PJ, McCutcheon SN, Tyrrell HF, Haaland GL (1986a) Effect of bovine growth hormone administration on metabolism of growing Hereford heifers: protein and lipid metabolism and plasma concentrations of metabolites and hormones. J Nutr 116, 2504-2515

Eisemann JH, Hammond AC, Rumsey TS, (1989) Tissue protein synthesis and nucleic acid concentrations in steers treated with somatotrophin. Br J Nutr 62, 657-671

Forbes EB, Kriss M, Braman WW, Jeffries CD, Swift RW, French RB, Miller RC, Smythe CV (1927) The influence of position of cattle as to standing and lying on the rate of metabolism. J Agric Res 35, 947-960

Fuller MF, Weekes TEC, Cadenhead A, Bruce JB (1977) The protein-sparing effect of car- bohydrate. II. The role of insulin. $B r J$ Nutr 38, 489-496

Gaesser GA, Brooks GA (1984) Metabolic bases of excess post-exercise oxygen consumption: a review. Med Sci Sports Exercise $16,29-43$

Garlick PJ (1980) Assessment of protein metabolism in the intact animal. In: Protein Deposition in Animals (Buttery PJ, Lindsay DB, eds) Butterworths, London, 51-68

Gartick PJ, Burck TL, Swick RW (1976) Protein synthesis and RNA in tissues of the pig. Am J Physiol 230, 1108-1112

Garlick PJ, Fern M, Preedy VR (1983) The effect of insulin infusion and food intake on muscle protein synthesis in post absorptive rats. Biochem J 210, 669-676

Gleeson M, Brown JF, Waring JJ, Stock MJ (1982) The effects of physical exercise and metabolic rate and dietary induced thermogenesis. Br J Nutr 47, 173-181

Gregg VA, Milligan LP (1980) Inhibition of $\mathrm{Na}^{+}$, $\mathrm{K}^{+}$ATPase of intact mouse soleus muscle by $\mathrm{Mg}^{2+}$. Biochem Biophys Res Commun 95, 608-611

Gregg VA, Milligan LP (1982a) Role of $\mathrm{Na}^{+}, \mathrm{K}+$ ATPase in muscular energy expenditure of warm- and cold exposed sheep. Canad $J$ Anim Sci 62, 123-132

Gregg VA, Milligan LP (1982b) In vitro costs of $\mathrm{Na}^{+}, \mathrm{K}^{+}$ATPase activity and protein synthesis in muscle from calves of differing age and breed. Br J Nutr 48, 65-71

Gregg VA, Milligan LP (1982C) $\mathrm{O}_{2}$ consumption and $\mathrm{Na}^{+}, \mathrm{K}^{+}$-ATPase-dependent respiration in muscle of lambs and lactating and nonlactating ewes. In: Energy Metabolism of Farm Animals (Ekern A, Sundstøl F, eds) Eur Assoc Anim Prod Publ 29. Informasjonsteknikk A/S, Ski, Norway, 66-69

Gronostajski RM, Pardee AB, Goldberg AL (1985) The ATP dependence of the degradation of short- and long-lived proteins in growing fibroblasts. $J$ Biol Chem 260, 3344-3349

Guernsey DL, Stevens ED (1977) The cell membrane sodium pump as a mechanism for increasing thermogenesis during cold acclimation in rats. Science 196, 908-910

Hall WC, Brody S (1933) Growth and development with special reference to domestic ani- 
mals. XXVI. The energy increment of standing over lying and the cost of getting up and lying down in growing ruminants (cattle and sheep): comparison of pulse rate, respiration rate, tidal air, and minute volume of pulmonary ventilation during lying and standing. Univ Mo Coll Agric Expt Stat Res Bull 180, 1-31

Harris PM, Garlick PJ, Lobley GE (1989) Interactions between energy and protein metabolism in the whole body and hind limb of sheep in response to intake. In: Energy Metabolism of Farm Animals (van der Honig $Y$, Close WH, eds) Eur Assoc Anim Prod Publ 43 Pudoc, Wageningen, 167-170

Hasselbach W, Oetliker H (1983) Energetics and electrogenicity of the sarcoplasmic reticulum $\mathrm{Ca}^{2+}$ pump. Ann Rev Physiol 45, 325339

Hermansen L, Grandmontagne M, Maehlum S, Ingnes I (1984) Med Sport Sci 17, 119-129

Hermansen L, Vaage $O$ (1977) Lactate disappearance and glycogen synthesis in human muscle after maximal exercise. Am J Physiol 233, E422-E429

Hornicke $H(1970)$ Circadian activity rhythms and energy cost of standing in growing pigs. In: Energy Metabolism of Farm Animals (Schurch A, Wenk C, eds) Eur Assoc Anim Prod Publ 13, Juhs Druck, Zurich, 165-168

Horwitz BA, Eaton M (1977) Ouabain-sensitive liver and diaphragm respiration in coldacclimated hamster. J Appl Physiol 42, 150153

Huntington GB (1990) Energy metabolism in the digestive tract and liver of cattle; influence of physiological stage and nutrition. Reprod Nutr Dev 30, 35-47

Huntington G, Eisemann J, Whitt J (1988) Proportions of whole body blood flow and oxygen uptake attributable to gut and liver of beef steers. Anim Sci 66 (suppl 1), 147

Ismail-Beigi $F$, Edelman IS (1971) The mechanism of the calorigenic action of thyroid hormone: stimulation of $\mathrm{Na}^{+}, \mathrm{K}^{+}$-activated adenosine triphosphatase activity. J Gen Physiol 40, 710-722

Jarrett IG, Filsell OH, Ballard FJ (1976) Utilisation of oxidisable substrates by the sheep hind limb: effects of starvation and exercise. Metabolism 25, 523-531
Jepson MM, Bates PC, Millward DJ (1988) The role of nutrition and thyroid hormones in the regulation of muscle growth and protein turnover in response to dietary protein in the rat. Br J Nutr 59, 397-415

Jessop NS, Smith GH, Crabtree B (1986) Measurement of a substrate cycle between acetate and acetyl-CoA in rat hepatocytes. Biochem Soc Trans 14, 146-147

Katz J, Rognstad R (1976) Futile cycles in metabolism of glucose. Curr Top Cell Regul 10, 237-289

Kim DH, Witzmann FA, Fitts RH (1982) Effect of thyrotoxicosis on sarcoplasmic reticulum in rat skeletal muscle. Am J Physiol 243, C151155

Ku-Vera JC, MacLeod NA, Ørskov ER (1989) Energy exchanges in cattle nourished by intragastric infusion of nutrients. In: Energy Metabolism of Farm Animals (van der Noning Y. Close W, eds) Pudoc, Wageningen, 271-274

Lewis SEM, Kelly FJ, Goldspink DF (1984) Preand post-natal growth and protein turnover in smooth muscle, heart and slow- and fasttwitch skeletal muscles of the rat. Biochem $J$ $217,517-526$

Lobley GE (1986) The physiological bases of nutrient responses: growth and fattening. Proc Nutr Soc 45, 203-214

Lobley GE (1988) Protein turnover and energy metabolism in animals: interactions in leanness and obesity. In: Leanness in Domestic Buds: Genetics, Metabolic and Hormonal Aspects (LeClerq B, Whitehead CC, eds) Butterworths-INRA

Lobley GE, Connell A, Buchan V (1987) Effect of food intake on protein and energy metabolism in finishing beef steers. $B r J$ Nutr 57 , 457-465

Lobley GE, Milne V, Lovie JM, Reeds PJ, Pennie $K(1980)$ Whole body and tissue protein synthesis in cattle. Br J Nutr 43, 491-502

Lundholm L, Svedmyr N (1965) Influence of adrenaline on blood flow and metabolism in the human forearm. Acta Physiol Scan 65, 344-351

MacDonald ML, Swick RW (1981) The effect of protein depletion and repletion on muscle protein turnover in the chick. Biochem J 194, $811-819$ 
Mandel LJ, Baladan RS (1981) Stoichiometry and coupling of active transport to oxidative metabolism in epithelial tissues. $A m J$ Physiol 240, F357-F371

McBride BW (1986) Cellular energy expenditure on $\mathrm{Na}^{+}, \mathrm{K}+$ transport and protein synthesis in hyperthyroid sheep. J Dairy Sci 69 (suppl 1), 194

McBride BW, Burton JH, Macleod GK (1987) Skeletal muscle energy expenditures associated with $\mathrm{Na}^{+}, \mathrm{K}^{+}$-transport and protein synthesis in somatotropin-treated lactating cows. J Dairy Sci 70 (suppl 1), 175

McBride BW, Early RJ (1987) Effect of feeding frequency on tissue protein synthesis and related energy expenditures in sheep. Canad $J$ Anim Sci67, 1190

McBride BW, Milligan LP (1985a) Influence of feed intake and starvation on the magnitude of $\mathrm{Na}^{+}, \mathrm{K}^{+}-$ATPase (EC 3.6.1.3)-dependent respiration in duodenal mucosa of sheep. $\mathrm{Br}$ J Nutr 53, 605-614

McBride BW, Milligan LP (1985b) Magnitude of ouabain-sensitive respiration in the liver of growing, lactating and starved sheep. $\mathrm{Br} J$ Nutr 54, 293-303

Melville S, McNurlan MA, McHardy KC, Broom J, Milne E, Calder AG, Garlick PJ (1989) The role of degradation in the acute control of protein balance in adult man: failure of feeding to stimulate protein synthesis as assessed by $L-\left[1-{ }^{13} \mathrm{C}\right]$ leucine infusion. Metabolism 38, 256-264

Michalak M, Famulksi K, Carafoli E (1984) The $\mathrm{Ca}^{2+}$-pumping ATPase in skeletal muscle sarcolemma. J Biol Chem 259, 15540-15547

Mickelson JR, Marsh BB (1980) Calcium uptake and release by skeletal muscle mitochondria. Cell Calcium 1, 119-128

Muramatsu T, Hiramoto $\mathrm{K}$, Tasaki I, Okumura J (1987) Whole body protein turnover in laying hens with reference to protein depletion and repletion. Nutr Rep Int 35, 607-614

Muramatsu T, Ueda Y, Hirata T, Okumura J, Tasaki I (1988) A note on the effect of ageing on whole-body protein turnover in goats. Anim Prod 46, 479-481

Newsholme EA, Crabtree BF (1976) Substrate cycles in metabolic regulation and in heat generation. Biochem Soc Symp 43, 183-205
Oddy VH, Gooden JM, Annison EF (1984) Partitioning of nutrients in merino ewes. I. contribution of skeletal muscle, the pregnant uterus and the lactating mammary gland to total energy expenditure. Aust J Biol Sci 37, 375388

Oddy VH, Lindsay DB (1986) Determination of protein synthesis, gain and degradation in intact hind-limb muscle of lambs. Biochem $J$ $233,417-425$

Oddy VH, Lindsay DB, Barker PJ, Northrop (1987) Effect of insulin on hind-limb and whole-body leucine and protein metabolism in fed and fasted lambs. $B r J$ Nutr 58,437 452

Palmer RM, Reeds PJ, Lobley GE, Smith RH (1981) The effect of intermittent changes in tension on protein and collagen synthesis in isolated rabbit muscles. Biochem J 198, 491498

Palsson H, Verges JB (1952) Effects of the plane of nutrition on growth and the development of carcass quality in lambs. I. Effects of high and low planes of nutrition at different ages. J Agric Sci (Camb) 42, 1-92

Pell JM, Bates PC (1987) Collagen and noncollagen protein turnover in skeletal muscle of growth hormone treated lambs. J Endocrinol 115, R1-R4

Pell JM, Caldarone EM, Bergman EN (1986) Levaine and $\alpha$-ketoisocaproate metabolism and interconversions in fed and fasted sheep. Metabolism 35, 1005-1016

Pethick DW, Lindsay DB, Barker PJ, Northrop AJ (1981) Acetate supply and utilisation by the tissues of sheep in vivo. Br J Nutr 46, 97110

Pethick DW, Harman N, Chong JK (1987) Nonesterifed long-chain fatty acid metabolism in fed sheep at rest and during exercise. Aust $J$ Biol Sci 40, 221-234

Preedy VR, Garlick PJ (1983) Protein synthesis in skeletal muscle of the perfused rat hemicorpus compared with rates in the intact animal. Biochem J 214, 433-442

Rabkin M, Blum JJ (1985) Quantitative analysis of intermediary metabolism in hepatocytes incubated in the presence and absence of glucagon with a substrate mixture containing glucose, ribose, fructose, alanine and acetate. Biochem J 225, 761-786 
Rapoport S, Dubiel W, Muller M (1985) Proteolysis of mitochondria in reticulocytes during maturation is accompanied by a high rate of ATP hydrolysis. FEBS Lett 180, 249-252

Reeds PJ, Cadenhead A, Fuller MF, Lobley GE, McDonald JD (1980) Protein turnover in growing pigs. Effects of age and food intake. Br J Nutr 43, 445-455

Reeds PJ, Fuller MF, Nicholson BA (1985) Metabolic basis of energy expenditure with particular reference to protein. In: Substrate and Energy Metabolism (Garrow JS, Halliday D, eds) John Libbey, London, 46-57

Reeds PJ, Lobley GE (1980) Protein synthesis: are there real species differences ? Proc Nutr Soc 39, 43-52

Rosenthal W, Hescheler J, Trautwein W, Schultz G (1988) Control of voltagedependent $\mathrm{Ca}^{2+}$ channels by $\mathrm{G}$ proteincoupled receptors. FASEB J 2, 2784-2790

Schaftingen van $E$ (1987) Fructose 2,6biphosphate. Adv Enzymol 59, 315-426

Sève B, Reeds PJ, Fuller MF, Cadenhead A, Hay SM (1986) Protein synthesis and retention in some tissues of the young pig as influenced by dietary protein intake after early weaning. Possible connection to the energy metabolism. Reprod Nutr Dev 26, 849-861

Siems W, Dubiet W, Dumdey R, Muller M, Rapoport SM (1984) Accounting for the ATPconsuming processes in rabbit reticulocytes. Eur J Biochem 139, 101-107

Simon O, Munchmeyer R, Bergner, H Zebrowska T, Buraczewska $L$ (1978) Estimation of rate of protein synthesis by constant infusion of labelled amino acids in pigs. $B r J$ Nutr 40 , 243-252

Simonides WS, Van Hardeveld C (1985) The effect of hypothyroidism on sarcoplasmic reticulum in fast-twitch muscle of the rat. Biochim Biophys Acta 855, 129-141

Sims JL, Berger SJ, Berger NA (1983) Poly (ADP-ribose) polymerase inhibitors preserve nicotinamide adenine dinucleotide and adenosine $5^{\prime}$-triphosphate pools in DNAdamaged cells: mechanism of stimulation of unscheduled DNA synthesis. Biochemistry 22, 5188-5194
Summers M, McBride BW, Milligan LP (1986) Components of basal energy expenditure. In: Aspects of Digestive Physiology in Ruminants (Dobson A, Dobson MJ, eds) Cornell Publishing Associates, Ithaca, 257-285

Summer R, Weekes TEC (1983) Effect of insulin infusion on nitrogen excretion in sheep. Proc Nutr Soc 42, 39A

Suzuki A (1971) Histochemical classification of individual skeletal muscle fibres in the sheep. I. On $M$. semitendinosus. $M$. longissimus dorsi, M. psoas major, M. latissimus dorsi and M. gastrocnemius. Jpn J Zootech Sci 42 , 39-53

Teleni E, Annison EF, Lindsay DB (1986) Metabolism of valine and the exchange of amino acids across the hind-limb muscles of ted and starved sheep. Aust J Biol Sci 39, 379393

Tung HYL, Pelech S, Fisher MJ, Pogson Cl, Cohen $P$ (1985) The protein phosphatases involved in cellular regulation: influence of polyamines on the activities of protein phosphatase-1 and protein phosphatase-2A. Eur $J$ Biochem 149, 305-313

Wainberg EF, Culbert LA, Fagan JM (1989) Energy depletion results in a $\mathrm{Ca}^{2+}$-dependent increase in protein breakdown in chick skeletal muscles. FASEB J 3, A340

Waterlow JC, Garlick PJ, Millward DJ (1978) Protein Turnover in Mammalian Tissues and in the Whole Body. Elsevier - North Holland, Amsterdam

Webster AJF (1981) The energetic efficiency of metabolism. Proc Nutr Soc 40, 121-128

Webster AJF, Osuji PO, White F, Ingram JF (1975) The influence of food intake on portal blood flow and heat production in the digestive tract of sheep. Br J Nutr 34, 125-139

Wenk C, Van Es AJH (1976) Energy metabolism of growing chickens as related to their physical activity. In: Energy Metabolism of Farm Animals (Vermorel M, ed) Eur Assoc Anim Prod Publ 19; De Bussac, ClermontFerrand, 189-192

Whittam $R$ (1961) Active ion transport as a pacemaker of respiration. Nature 191, 603604 
Williams RS, Lefkowitz R (1983) The effects of thyroid hormone on adrenergic receptors. In: The Molecular Basis of Thyroid Hormone ACtion (Oppenheimer JH, Samuels $\mathrm{HH}$, eds) Academic Press, New York, 325-351

Wool G (1960) Incorporation of ${ }^{14} \mathrm{C}$-amino acids into proteins of isolated diaphragms: effects of epinephrine and norepinephrine. $A m J$ Physiol 198, 54-56

Young VR, Gucalp C, Rand WM, Matthews DE, Bier DM (1987) Leucine kinetics during three weeks at submaintenance-to-maintenance intakes of leucine in man; adaptation and accommodation. Human Nutr Clin Nutr 41c, 118 